\title{
EFFECT OF CLASS MANAGEMENT ON THE DEVELOPMENT OF STUDENTS' CHARACTER IN SMK NEGERI 1 TORAJA UTARA
}

\author{
Zetni Podang Sappetau 1, Bernadetha Nadeak ${ }^{2}$ 圧, Dameria Sinaga ${ }^{3}$ \\ 1,2,3 Magister of Education Management Department, Postgraduate Program, Universitas Kristen \\ Indonesia, Jakarta
}

DOI: https://doi.org/10.29121/granthaalayah.v9.i2.2021.3527

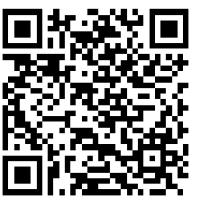

Article Type: Research Article

Article Citation: Zetni Podang Sappetau, Bernadetha Nadeak, and Dameria Sinaga. (2021). EFFECT OF CLASS MANAGEMENT ON THE DEVELOPMENT OF STUDENTS' CHARACTER IN SMK NEGERI 1 TORAJA UTARA. International Journal of Research GRANTHAALAYAH, 9(2), 257-265. https://doi.org/10.29121/granthaa layah.v9.i2.2021.3527

Received Date: 30 January 2021

Accepted Date: 27 February 2021

Keywords:

Character Education

Classroom Management

Vocational School

\begin{abstract}
This research aims to find out how the class management in SMKN1 Toraja Utara, how the implementation of character education in SMKN1 Toraja Utara, and to know how much impact the management of the class on character education in SMKN 1 Toraja Utara. The method used in this research is descriptive qualitative. Descriptive methods describe the state of the data without compromising or adding data as is. The results showed a positive correlation between class management and character development is 0.328 , categorized as being in a weak category. while the value of sig. (2-tailed) of 0.002 were less than 0.05 , so it can be concluded that the relationship between class management variables and character development is significant. In contrast, the value of $\mathrm{R}$ Square or the coefficient of determination is 0.108 . It means that the percentage of class management variable capability size explains the variation of character development variable in SMKN 1 Toraja Utara by $10.8 \%$ while the rest is determined by other variables/factors not included in this study.
\end{abstract}

\section{INTRODUCTION}

Character strengthening is a program of President Jakowi Widodo and Vice President Jusuf Kalla in this case, and the point is to revolutionize the nation's character. The movement to strengthen character education encourages national education to be a concern for all [1]. There are five character education priorities, namely religion, nationalism, integrity, self-reliance, and cooperation.

With the advancement of science and technology today and the diverse demands of various sectors of economic life, it is needed the development of human resources [2]. For human is the main actors or the main drivers in why a goal - the nation-building, empowerment of qualified human resources become demands in the world of education in carrying out its functions and is a vital industry that is expected to be able to push a country and nation towards national goals. By understanding the importance of education for human welfare, "Law No.20 of 2003 concerning the National Education System states: "National education serves to educate the life of the nation through the development of abilities and the formation of dignified national character and civilization in the world community" [3]. The education process is the main thing for forming quality human resources, insightful, critical thinking, intelligent, unpretentious, to improve the standard of human life. According to the National Education System states:

(C) 2021 The Author(s). This is an open access article distributed under the terms of the Creative Commons Attribution License, which permits unrestricted use, distribution, and reproduction in any medium, provided the original author and source are credited. 
"National education is expected to be able to explore the ability of students as human beings who believe and fear God almighty, healthy physically and spiritually, knowledgeable, honest, have a dedication to developing self-capable entrepreneurship and democracy and full of responsibility in order to educate the life of the nation" [4].

The progress of the times requires the empowerment of competent human resources. The Indonesian nation can compete with countries in the world, especially in free trade in terms of its outcome and human resources. The government's actions to increase quality middle-level human resources are the development of vocational secondary education. In this case, vocational education will equip students to work in one particular area of expertise. However, the skills possessed by each student must be included with good character education in order to be able to manage the work and be able to interact with the surrounding environment so that the work done can be more maximal [5]. The character of each human being contains things that contain life skills received from God, expressed in actions, speech, feelings, which are based on religious norms, laws, manners, habituation, culture, and customs. Character is a particular unique value that is ingrained in a person through his behaviour.

For character education in students consists of character values' practice, which contains the value of knowledge, effectiveness, awareness or desire, and ways to do good things, to God, himself, others, the environment, and the state [6]. Implementation of character education in SMKN1 Toraja Utara, involving components (stakeholders), supporting elements of education, such as curriculum content, teaching and evaluation process, cooperation, coordination, school management, planning activities or activities outside of learning hours, improvement of infrastructure, finance, and participation of all residents and school environment

The essential role in building the character of learners is the management of learning in the classroom. Educators carry out class management intending to present excellent conditions for creating learning processes in the classroom [7]. Class management deals with ways to shape and maintain a pleasant atmosphere so that the learning process runs conductively. Implementation of character education in schools is the responsibility of management relationships or school leaders. In this case, planning, organizing, command, coordinator, overall control is controlled in a fair educational process [8]. Character education consists of components that need to be instilled, curriculum content, learning, evaluation, educators and non-educational personnel, and other things.

Teachers are expected to build a conducive, comfortable and enjoyable learning environment and provide good character education for more useful learners. That can make students feel happy and excited about learning activities in the classroom [9]. Character education is carried out in an integrated way in schools, against the background that students will experience growth and develop well if directly involved in the teaching and learning process. Gaining learning experience in a meaningful sense [10]. Systematic teaching can be interpreted as an understanding of learning approaches that activate several science areas to instil valuable knowledge for students [11].

Character education can be done by modelling or being an example to realize. The form that can be used in this strategy is that teacher acts as an example of a good example. Students must follow the model who has a noble character, and the teacher can solve every problem well, speak politely to the learner and be able to convince the student properly, is a form of behaviour expected by each student [12]. Habituation pattern in the application of ethics is a significant level that should accompany every learning activity. Moral teaching without habituation will be useless because the cultivation of ethics is not just knowledge, but habituation in ethics.

The ideals and laws expect character education, but the conditions that we are experiencing now have changed to the value. With the emergence of abusive behaviours of social norms and cultural values, increasing consumeristic and hedonistic lifestyles, many parents are disappointed with their teenage children's actions that are difficult to foster. Similarly, teachers who at all times deal with the behaviour of diverse teenage students. Students who used to respect the value of honesty, but in reality, that size is tarnished by instant grades and do not have to work hard, for example, do not need to learn to get good grades, because by asking friends and opening books and buying right value answers it will be able to be achieved and levelled up or graduated. Social demands and the desire to maintain self-esteem in the eyes of peers have encouraged cheating to become commonplace and mandatory. Fast-paced value has replaced the value of honesty [13]. In addition to cheating, other deviant habits can be made by learners including unlimited association, kebo gathering, smoking in school, stealing, skipping, fighting teachers, consuming liquor and drugs, engaging in fighting, getting pregnant before marriage, viewing porn, which lowers the character of the learner.

In class management concerning curriculum content planning, planning and learning resources, it structures class elements, observes student development, and tackles obstacles that arise in the classroom. The function of Class Management is so that the learning process can be carried out in an integrated manner, to make it easier to follow the progress and development of students and to solve obstacles that need to be discussed in the classroom 
in order to improve teaching patterns in the future including problems in social life [14]. One of the successes of students in the learning process is the teacher's learning strategy. Teachers are expected to know the essential tools in conducting the learning process in the classroom. Therefore, educators are expected to understand the philosophy of learning and teaching activities. Teaching is transferring or transferring knowledge and several characters that need to be instilled in students.

Class management organizes learning, facilities and infrastructure and rutunitas and concerns preparing the classroom and school environment to achieve a conducive atmosphere and a fair and enjoyable learning process. Therefore, schools need to be well organized, thus creating conducive teaching and learning conditions. Duties and responsibilities to help young people deal with the dynamics of life are generally given to schools. "Schools are expected to be the centre of community change or the site of a mental revolution".

\section{THEORETICAL REVIEW}

Management is defined as "a field of science that strives systematically to understand why and how humans work together to achieve goals and make this system more beneficial to humanity" [15]. Management is a typical process consisting of planning, organizing, implementing, and supervising each field is used both science and expertise and which is followed sequentially to achieve the goals that have been set" [16].

Planning is a series of activities to know the direction of the goals achieved by an organization and establish the most appropriate means to be used to achieve the objectives. "Planning is the selecting and relating of facts and the making and using of assumption regarding the future the visualization and formulation of proposed activities, believe necessary to achieve desired results" [17]. In the planning, three elements must be considered: data collection, fact analysis, and practical planning.

Planning cannot control the time to come, but planning can predict what will happen, capturing the opportunities and challenges that will be faced. Planning objectives include: 1) to provide guidance both to the leadership and to the staff; 2) to reduce uncertainty because, with planning, a leader looks far ahead; 3 ) to minimize waste; 4) planning aims to determine the objectives and standards used to facilitate evaluation and supervision [18], [19]. At the organizing stage, there is a process of determining formal relationships between personnel and existing resources. This function concerns all actions that are thought to be planned into a structure of responsibility and authority. In this case, a manager must create job specifications, job descriptions and job definitions. The definition of work should be based on specialization by dividing or grouping work, making it easier to supervise [20], [21], [22].

"Organizing is the establishment of the effective behavioural relationship among persons, so that they may work together efficiently and gain personal satisfaction in doing selected tasks under given environmental conditions to achieve some goal or objective" [23], [24]. This opinion confirms that organizing provides a clear breakdown of related tasks among personnel to work well together to achieve the goals set.

Briefing as an effort of a leader in interacting with staff both individually and in groups. A leader must be able to direct the staff to be able to work towards a common goal. Briefings are essential, considering people are usually unpredictable because they have unique attitudes and personalities. A manager invites every personnel in the organization he leads to contribute through cooperation in a briefing effort. The briefing can be done by providing motivation that can be an encouragement for every person to work optimally.

Controlling or supervision is a significant activity in an organization. Supervision activities include monitoring the process of activities carried out by workers to ensure that they carry out their responsibilities following the planned expectations and correct any irregularities. The controlling function consists of actions and decisions managers undertake to ensure that actual results are consistent with the desired result [25], [26]. The function of control or supervision concerns the efforts and decisions to ensure that the results achieved by the organization can be consistent with the results set out in the planning.

"Class Management is defined as the ability of teachers or homeroom teachers in utilizing the potential of the classroom in the form of providing the widest opportunities in each person to conduct creative and targeted activities so that the time and funds available can be utilized efficiently to conduct classroom activities related to curriculum and student development" [27], [28]. Meanwhile, Adnan Sulaeman said that "Classroom management is a series of teacher behaviours to create and maintain classroom conditions that enable learners to achieve their learning goals efficiently or enable learners to learn well". 


\section{RESEARCH METHOD}

The method used in this research is descriptive qualitative. Descriptive methods describe the state of data without compromising or adding data. Qualitative research type is to examine objects' condition naturally where the essential instruments are people, humans, or researchers themselves. Qualitative research has the characteristics of natural background that is the data obtained is a reality that is intact following the context. That means that a researcher enters the research area to obtain data firsthand without manipulating it. Research data is sourced from primary data. Primary data is empirical data needed to test hypotheses. Primary data is obtained through perception measurement, and for that, it is structured questioner-shaped measuring instruments containing questions or statements using a Likert scale. At the same time, secondary data is obtained from existing data in schools.

\section{RESULT AND DISCUSSION}

Before the instrument is distributed to all respondents, the instrument made is given to 20 respondents and tested to determine if the instrument is valid or not and whether they make reliabel.

Table 1: Validity Test Results

\begin{tabular}{|c|c|c|c|c|}
\hline & & X_TOTAL & r TABEL & KESIMPULAN \\
\hline X_ITEM1 & Pearson Correlation & $.521^{\circ}$ & 0.444 & VALID \\
\hline X_ITEM2 & Pearson Correlation & $500^{\circ}$ & 0.444 & VALID \\
\hline X_ITEM3 & Pearson Correlation & $.661^{\prime \prime}$ & 0.444 & VALID \\
\hline X_ITEM4 & Pearson Correlation & $.542^{\circ}$ & 0.444 & VALID \\
\hline X_ITEM5 & Pearson Correlation & $.677^{*}$ & 0.444 & VALID \\
\hline X_ITEM6 & Pearson Correlation & $.713^{\prime \prime}$ & 0.444 & VALID \\
\hline X_ITEM7 & Pearson Correlation & $.761^{\prime \prime}$ & 0.444 & VALID \\
\hline X_ITEM 8 & Pearson Correlation & $.657^{*}$ & 0.444 & VALID \\
\hline X_ITEM9 & Pearson Correlation & $.545^{\circ}$ & 0.444 & VALID \\
\hline X_ITEM10 & Pearson Correlation & $.642^{\prime \prime}$ & 0.444 & VALID \\
\hline X_ITEM11 & Pearson Correlation & $.587^{\circ}$ & 0.444 & VALID \\
\hline X_ITEM12 & Pearson Correlation & $.621 "$ & 0.444 & VALID \\
\hline X_ITEM13 & Pearson Correlation & $.618^{*}$ & 0.444 & VALID \\
\hline X_ITEM14 & Pearson Correlation & $.560^{\circ}$ & 0.444 & VALID \\
\hline X_ITEM15 & Pearson Correlation & $.639^{\prime \prime}$ & 0.444 & VALID \\
\hline X_ITEM16 & Pearson Correlation & $.555^{\circ}$ & 0.444 & VALID \\
\hline X_ITEM17 & Pearson Correlation & $.597^{*}$ & 0.444 & VALID \\
\hline X_ITEM18 & Pearson Correlation & $.770^{-1}$ & 0.444 & VALID \\
\hline X_ITEM19 & Pearson Correlation & $.639^{\prime \prime}$ & 0.444 & VALID \\
\hline X_ITEM20 & Pearson Correlation & $.648^{\prime \prime}$ & 0.444 & VALID \\
\hline X_ITEM21 & Pearson Correlation & $.539^{\circ}$ & 0.444 & VALID \\
\hline X_ITEM 22 & Pearson Correlation & $.535^{\circ}$ & 0.444 & VALID \\
\hline X_ITEM23 & Pearson Correlation & $.468^{\circ}$ & 0.444 & VALID \\
\hline X_ITEM24 & Pearson Correlation & $.498^{\circ}$ & 0.444 & VALID \\
\hline X_ITEM 25 & Pearson Correlation & $.699^{\prime \prime}$ & 0.444 & VALID \\
\hline X_ITEM26 & Pearson Correlation & $.523^{+}$ & 0.444 & VALID \\
\hline
\end{tabular}

* Correlation is significant at the 0.05 level (2-tailed)

The above table shows that the $r$ value for all items is more than 0.444 , so it can be concluded that the statement items in the Class Management variable are all valid.

Table 2: Reliability Test Results

Reliability Statistics

\begin{tabular}{|r|r|}
\hline $\begin{array}{l}\text { Cronbach's } \\
\text { Alpha }\end{array}$ & N of Items \\
\hline .928 & 26 \\
\hline
\end{tabular}


Obtained a reliability coefficient of 0.928 where more than $r$ table $(0.444)$ it can be concluded that the details of the statement in the variable Management Class X1 reliabel

Table 3: Test Normality

\begin{tabular}{|l|r|r|r|r|r|r|}
\hline \multirow{2}{*}{} & \multicolumn{3}{|c|}{ Kolmogorov-Smirnov } & \multicolumn{3}{c|}{ Shapiro-Wilk } \\
\cline { 2 - 8 } & Statistic & \multicolumn{1}{|c|}{ df } & \multicolumn{1}{c|}{ Sig. } & \multicolumn{1}{c|}{ Statistic } & \multicolumn{1}{c|}{ df } & \multicolumn{1}{c|}{ Sig. } \\
\hline MANAGEMEN_KELAS & .079 & 86 & $.200^{\circ}$ & .988 & 86 & .597 \\
\hline
\end{tabular}

*. This is a lower bound of the true significance.

a. Lilliefors Significance Correction

Based on SPSS results above, obtained the significance value of Kolmogorov-Smirnov variable Compensation of 0.200 where $>0.05$ so that it can be concluded that the data in class management variables are distributed normally.

Table 4: Validity Test Results

\begin{tabular}{|c|c|c|c|c|}
\hline \multicolumn{5}{|c|}{ Correlations } \\
\hline & & Y_TOTAL & r TABEL & KESIMPULAN \\
\hline Y_ITEM1 & Pearson Correlation & $.584^{* \prime}$ & 0.444 & VALID \\
\hline Y_ITEM2 & Pearson Correlation & $.846^{* \prime}$ & 0.444 & VALID \\
\hline Y_ITEM3 & Pearson Correlation & $.563^{* \prime}$ & 0.444 & VALID \\
\hline Y_ITEM4 & Pearson Correlation & $.514^{\circ}$ & 0.444 & VALID \\
\hline Y_ITEM5 & Pearson Correlation & $.785^{*}$ & 0.444 & VALID \\
\hline Y_ITEM6 & Pearson Correlation & $.867^{* *}$ & 0.444 & VALID \\
\hline Y_ITEM7 & Pearson Correlation & $.747^{\prime \prime}$ & 0.444 & VALID \\
\hline Y_ITEM8 & Pearson Correlation & $.548^{\circ}$ & 0.444 & VALID \\
\hline Y_ITEM9 & Pearson Correlation & $.600^{* \prime}$ & 0.444 & VALID \\
\hline Y_ITEM10 & Pearson Correlation & $.548^{\circ}$ & 0.444 & VALID \\
\hline Y_ITEM11 & Pearson Correlation & $.630^{* *}$ & 0.444 & VALID \\
\hline Y_ITEM12 & Pearson Correlation & $.728^{*}$ & 0.444 & VALID \\
\hline Y_ITEM13 & Pearson Correlation & $.719^{* \prime}$ & 0.444 & VALID \\
\hline Y_ITEM14 & Pearson Correlation & $.546^{\circ}$ & 0.444 & VALID \\
\hline Y_ITEM15 & Pearson Correlation & $.841^{\prime \prime}$ & 0.444 & VALID \\
\hline Y_ITEM16 & Pearson Correlation & $.662^{* *}$ & 0.444 & VALID \\
\hline Y_ITEM17 & \begin{tabular}{|l|} 
Pearson Correlation \\
\end{tabular} & $.471^{\circ}$ & 0.444 & VALID \\
\hline Y_ITEM18 & Pearson Correlation & $.722^{* *}$ & 0.444 & VALID \\
\hline
\end{tabular}

The above table shows that the $\mathrm{r}$ value for all items is more than 0.444 , so it can be concluded that the statement items in the Class Management variable are all valid.

Table 5: Reliability Test Results

\begin{tabular}{|c|c|}
\hline Reliability & atistics \\
\hline $\begin{array}{c}\text { Cronbach's } \\
\text { Alpha }\end{array}$ & $\mathrm{N}$ of Items \\
\hline .92 & 18 \\
\hline
\end{tabular}

Obtained a reliability coefficient of 0.926 where more than $r$ table $(0.444)$ can be concluded that the statement items in the variable Management Class X1 reliable 
Table 6: Test Normality

\begin{tabular}{|l|r|r|r|r|r|r|}
\hline \multicolumn{1}{|c|}{ Tests of Normality } \\
\cline { 2 - 7 } & \multicolumn{3}{|c|}{ Kolmogorov-Smirnov } & \multicolumn{3}{c|}{ Shapiro-Wilk } \\
\cline { 2 - 8 } & Statistic & \multicolumn{1}{c|}{ df } & \multicolumn{1}{c|}{ Sig. } & \multicolumn{1}{c|}{ Statistic } & df & \multicolumn{1}{c|}{ Sig. } \\
\hline $\begin{array}{l}\text { PERKEMBANGAN_KARAK } \\
\text { TER }\end{array}$ & .081 & 86 & $.200^{\circ}$ & .982 & 86 & .272 \\
\hline
\end{tabular}

*. This is a lower bound of the true significance.

a. Lilliefors Significance Correction

The results of the SPSS process for correlation appear as follows:

Table 7: Correlation Analysis

\begin{tabular}{|c|c|c|c|}
\hline \multicolumn{4}{|c|}{ Correlations } \\
\hline & & $\begin{array}{l}\text { MANAJEMEN_ } \\
\text { KELAS }\end{array}$ & $\begin{array}{c}\text { PERKEMBANG } \\
\text { AN_KARAKTE } \\
\mathrm{R}\end{array}$ \\
\hline \multirow{4}{*}{ MANAJEMEN_KELAS } & Pearson Correlation & 1 & $.328^{*}$ \\
\hline & Sig. (2-tailed) & & .002 \\
\hline & $\mathrm{N}$ & 86 & 86 \\
\hline & Pearson Correlation & $.328^{*}$ & 1 \\
\hline \multirow{2}{*}{$\begin{array}{l}\text { PERKEMBANGAN_KARAK } \\
\text { TER }\end{array}$} & Sig. (2-tailed) & .002 & \\
\hline & $\mathrm{N}$ & 86 & 86 \\
\hline
\end{tabular}

**. Correlation is significant at the 0.01 level (2-tailed).

Based on the above results obtained correlation coefficient between class management variables and character development is 0.328 , during sig value. (2-tailed) of 0.002 were less than 0.05 , so it can be concluded that the relationship between class management variables and character development is significant. follows:

The results of the regression analysis between class management variables and character development are as

Table 8: Regression Analysis

\begin{tabular}{|l|r|r|r|r|}
\hline Model & \multicolumn{1}{|c|}{ Model Summary } \\
\hline 1 & R Square & \multicolumn{1}{c|}{$\begin{array}{c}\text { Adjusted R } \\
\text { Square }\end{array}$} & $\begin{array}{c}\text { Std. Error of the } \\
\text { Estimate }\end{array}$ \\
\hline
\end{tabular}

a. Predictors: (Constant), MANAJEMEN_KELAS

b. Dependent Variable: PERKEMBANGAN_KARAKTER

Based on the SPSS output above, it also appears that R Square value or the coefficient of determination value is 0.108. It means that the percentage of class management variable capability size explains the variation of character development variable $10.8 \%$ while the rest is determined by other variables/factors not included in this study.

Table 9: Test Result F

\begin{tabular}{|c|c|c|c|c|c|c|}
\hline \multicolumn{7}{|c|}{ ANOYAa } \\
\hline & & Sum of Squares & df & Mean Square & $\mathrm{F}$ & Sig. \\
\hline \multirow{3}{*}{1} & Regression & 1.276 & 1 & \multirow{3}{*}{$\begin{array}{r}1.276 \\
.126\end{array}$} & \multirow[t]{3}{*}{10.140} & \multirow[t]{3}{*}{$.002^{\mathrm{b}}$} \\
\hline & Residual & 10.571 & 84 & & & \\
\hline & Total & 11.847 & 85 & & & \\
\hline
\end{tabular}


The $\mathrm{F}$ test result above shows a significance value (Sig.) of 0.002 was less than 0.05 , meaning that the $\mathrm{X} 1$ variable affects the variable $Y$, in other words, the class's management affects the character development variable.

Table 10: Test Result

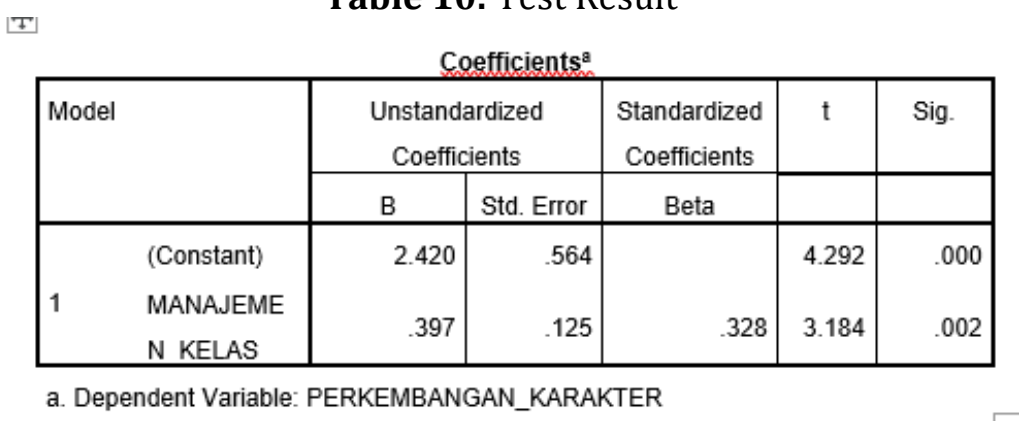

The $\alpha$ value or constant value is 2,420. It means that if the Class Management value (X) is 0 , then the Character Development value (Y) is 2,420. The $\beta$ or class management regression coefficient value (X) is 0.397 . It means that if the Class Management value increases by 1 unit, then character development $(Y)$ will increase by 0.397. Obtained a positive value regression coefficient. It means that the more the Class Management, the more the Character Development. If it is associated with a research hypothesis, then HO is rejected, and Ha is accepted. It means that Class Management (X) affects Character Development (Y). Judging from the significance value (Sig.) in the t-test, it appears that the value of X significance is 0.002 were less than $0.05(0.002<0.05)$. It means that Class Management (X) affects Character Development (Y). In the research hypothesis, H0 rejected Ha accepted.

Table 11: Linearity Test Results ANOVA Table

\begin{tabular}{|c|c|c|c|c|c|c|c|}
\hline & & & $\begin{array}{c}\text { Sum of } \\
\text { Squares }\end{array}$ & $\mathrm{df}$ & $\begin{array}{l}\text { Mean } \\
\text { Square }\end{array}$ & $\mathrm{F}$ & Sig. \\
\hline \multirow{7}{*}{$\begin{array}{l}\text { PERKEMBANGA } \\
\text { N_KARAKTER * } \\
\text { MANAGEMEN_K } \\
\text { ELAS }\end{array}$} & & (Combined) & 953.976 & $\overline{26}$ & 36.691 & 1.632 & .061 \\
\hline & Retween & Linearity & 244.621 & 1 & 244.621 & 10.881 & .002 \\
\hline & Groups & Deviation & & & & & \\
\hline & & from & 109.355 & 25 & $28.3 / 4$ & 1.262 & .229 \\
\hline & \multirow{2}{*}{\multicolumn{2}{|c|}{ Within Groups }} & 132635 & & & & \\
\hline & & & $\begin{array}{r}1320.35 \\
0\end{array}$ & 59 & 22.481 & & \\
\hline & \multicolumn{2}{|l|}{ Total } & $\begin{array}{r}2280.32 \\
6\end{array}$ & 85 & & & \\
\hline
\end{tabular}

Because the significance value in linearity is 0.002 where less than 0.05 it can be concluded that there is a linear relationship between character development and class management.

\section{CONCLUSIONS}

This study's conclusions are as follows: a) The lowest value of a class management variable is 3.77 , with a high of 4.88. the extensive range is 1.12 , and the average value is 4.27 , so it can be concluded that the class management variables in SMKN 1 Toraja Utara are in an excellent category. The lowest value of a character development variable is 3.39 , with a high of 4.72 . the extensive range is 1.33 , and the average value is 4.10 , so it can be concluded that the class management variables in SMKN 1 Toraja Utara are in a suitable category. A positive correlation between class management and character development is 0.328 , which is categorized as being in a weak category. while the value of sig. (2-tailed) of 0.002 were less than 0.05 , so it can be concluded that the relationship between class management variables and character development is significant. In comparison, the value of $\mathrm{R}$ Square or the coefficient of determination is 0.108 .

It means that the percentage of class management variable capability size explains the variation of character development variable in SMKN 1 Toraja Utara by $10.8 \%$ while the rest is determined by other variables/factors not included in this study. While the advice that researchers can give is as follows: a) To improve the management of the 
classroom, before starting the learning, teachers need to provide discipline for learners in the learning process; b) To improve character building, students need to improve honesty and foster trustworthy attitudes in their words and actions; c) In order for class management to have more impact on character development, it is necessary to maximize matters related to the class management process at SMKN 1 Toraja Utara; d) Character education needs to be designed to be more attractive and following the context of the surrounding environment; e) The government needs to issue a school manual for the Development of Cultural Education and National Character; f) In order for character education to run effectively, character education needs to include three basic approaches, which are classbased character education, school culture and community.

\section{SOURCES OF FUNDING}

This research received no specific grant from any funding agency in the public, commercial, or not-for-profit sectors.

\section{CONFLICT OF INTEREST}

The author have declared that no competing interests exist.

\section{ACKNOWLEDGMENT}

None.

\section{REFERENCES}

[1] Naibaho, L. (2014). The Role of Education and Culture in the Development of Character and Civilization of the Plural Indonesian Nation. Jurnal the Ary Suta Center Series on Strategic Management, 27(0), 69.

[2] Nadeak, B., Naibaho, L., Sormin, E., \& Juwita, C. P. (2019). Healthy Work Culture Stimulate Performance. Indian Journal of Public Health Research \& Development, 10(6), 1385-1389.

[3] Nadeak, B., \& Naibaho, L. (2020). The Effectiveness of Problem-Based Learning on Students' Critical Thinking. Jurnal Dinamika Pendidikan, 13(1), 1-7.

[4] Evans, M. (2010). Education and the ethics of democratic character. Synthesis philosophica, 25(1), 77-91.

[5] Tyas, E. H., \& Naibaho, L. (2020). Building Superior Human Resources through Character Education. TEST Engineering \& Management, 83, 11864-11873.

[6] Arthur, J., Kristjánsson, K., Harrison, T., Sanderse, W., \& Wright, D. (2016). Teaching character and virtue in schools. Routledge.

[7] Baehr, J. (2017). The varieties of character and some implications for character education. Journal of youth and adolescence, 46(6), 1153-1161.

[8] Burke, W. W., \& Noumair, D. A. (2015). Organization development: A process of learning and changing. FT Press.

[9] Sormin, E., Julianti, K., Nadeak, B., \& Naibaho, L. (2019). Use of construction inquiri learning model to improve the interest of learning students grade XI SMA Angkasa 2 in coloid materials. PEOPLE International Journal of Social Sciences, 5(2), 908-917.

[10] Nadeak, B., \& Naibaho, L. (2018). The Description of medical students' interest and achievement on anatomy at faculty of medicine Universitas Kristen Indonesia. International Journal of Sciences: Basic and Applied Research (IJSBAR), 39(1), 121-133.

[11] Tyas, E. H., \& Naibaho, L. (2021). HOTS Learning Model Improves The Quality Of Education. International Journal of Research-GRANTHAALAYAH, 9(1), 176-182.

[12] Nadeak, B. (2014). Pendidikan Multikultural Menuju Pendidikan yang Humanis. Jurnal Pendidikan dan Teologi Kristen (AREOPAGUS), 12(1), 67-75.

[13] Barnes, C., Blake, H., \& Pinder, D. (2009). Creating and delivering your value proposition: Managing customer experience for profit. Kogan Page Publishers. 
[14] Foster, J., \& Yaoyuneyong, G. (2016). Teaching innovation: equipping students to overcome real-world challenges. Higher Education Pedagogies, 1(1), 42-56.

[15] Nadeak, B., \& Naibaho, L. (2019). Managing Lecturers' Competence Development at Universitas Kristen Indonesia.

[16] Cassell, C., Worley, J. M., \& Doolen, T. L. (2006). The role of communication and management support in a lean manufacturing implementation. Management decision.

[17] Sheppard, S. R., Shaw, A., Flanders, D., Burch, S., Wiek, A., Carmichael, J., ... \& Cohen, S. (2011). Future visioning of local climate change: a framework for community engagement and planning with scenarios and visualisation. Futures, 43(4), 400-412.

[18] Kerzner, H. (2017). Project management: a systems approach to planning, scheduling, and controlling. John Wiley \& Sons.

[19] Shobrys, D. E., \& White, D. C. (2002). Planning, scheduling and control systems: why cannot they work together. Computers \& Chemical Engineering, 26(2), 149-160.

[20] Nadeak, B. (2019). Effects of Servant Leadership and Training Programs on Servant motivation of Hospital Medical Personnel. Indian Journal of Public Health Research \& Development, 10(9), 1772-1775.

[21] Nadeak, B., Naibaho, L., \& Silalahi, M. (2020). COVID-19 and Students' Anxiety Management. International Journal of Innovation, Creativity and Change, 13(7), 1574-1587.

[22] Naibaho, L., \& Sangga, R. E. (2019). Improving Eight Graders' Reading Comprehension Using Student Team Achievement Division (STAD) at SMP Strada Santo Fransiskus.

[23] Tannenbaum, R., Weschler, I., \& Massarik, F. (2013). Leadership and organization (RLE: organizations): A behavioural science approach. Routledge.

[24] Nadeak, B., Iriani, U. E., Naibaho, L., Sormin, E., \& Juwita, C. P. (2019). Building Employees' Mental Health: The Correlation between Transactional Leadership and Training Program with Employees' Work Motivation at XWJ Factory. Indian Journal of Public Health Research \& Development, 10(6), 1373-1379.

[25] Langfield-Smith, K. (1997). Management control systems and strategy: a critical review. Accounting, organizations and society, 22(2), 207-232.

[26] Armstrong, M., \& Baron, A. (2005). Managing performance: performance management in action. CIPD publishing.

[27] Manny-Ikan, E., Dagan, O., Tikochinski, T., \& Zorman, R. (2011). [Chais] Using the Interactive White Board in Teaching and Learning-An Evaluation of the Smart Classroom Pilot Project. Interdisciplinary Journal of ELearning and Learning Objects, 7(1), 249-273.

[28] Naibaho, L. (2019). The Effectiveness of Scaffolding Method on Students' Speaking Achievement. International Journal of Research-Granthaalayah, 7(5), 193-201. 